

\title{
MENINGKATKAN KEMAMPUAN BELAJAR SENAM AEROBIK MELALUI PENERAPAN METODE KOMANDO PADA SISWA KELAS XI SMA NEGERI 7 AMBON
}

\author{
Deslin Lewankey ${ }^{1}$ Johanna Matitaputy \\ jokematitaputty0@gmail.com
}

\begin{abstract}
ABSTRAK
Penelitian ini bertujuan untuk mengetahui kemampuan belajar senam aerobic pada siswa kelas XI SMA Negeri 7 Ambon melalui penerapan metode komando. Metode penelitian ini merupakan penelitian tindakan kelas melalui metode komando dalam pembelajaran senam aerobik,. Subjek dalam penelitian ini adalah siswa-siswi di SMA Negeri 7 Ambon yang berjumlah 21 siswa. Berdasarkan uji hipotesis, maka hasil penelitian ini menunjukan bahwa SMA Negeri 7 Ambon menunjukan adanya peningkatan yang cukup berarti dalam setiap siklusnya. Pada siklus yang pertama setelah diterapkan metode komando diperoleh nilai rata-rata kemampuan belajar siswa $74,76 \%$ atau ada 13 siswa yang sudah tuntas belajar. Hasil tersebut menunjukkan bahwa pada siklus pertama secara klasikal siswa belum tuntas belajar, karena siswa yang memperoleh nilai $\geq 75$ hanya sebesar $63,50 \%$ lebih kecil dari presentase ketuntasan yang di kehendaki yaitu $75 \%$ dan dilanjutkan pada siklus yang kedua, dan pada siklus yang kedua ini siswa-siswi yang belum tuntas pada siklus yang pertama semuanya menjadi tuntas. Hal ini menunjukan bahwa penerapan metode komando dapat meningkatkan kemampuan belajar senam aerobic.
\end{abstract}

Kata Kunci : Metode Komando, Senam Aerobik, kemampuan Belajar 


\section{PENDAHULUAN}

Pendidikan merupakan kebutuhan penting bagi setiap manusia. Selain itu pendidikan adalah sektor yang strategis untuk mencerdaskan kehidupan bangsa sehingga diperoleh sumber daya manusia (SDM) yang berkualitas. Karena itu, pendidikan harus ditumbuhkembangkan secara sistematis, sehingga tercipta suatu sistem pendidikan yang dapat menghasilkan SDM yang berkualitas.

Peningkatan mutu pendidikan harus dilakukan secara menyeluruh yang meliputi beberapa aspek antara lain aspek moral, pengetahuan, keterampilan, seni, olahraga dan perilaku. Pendidikan dapat dilakukan secara formal, maupun nonformal. Pendidikan formal diperoleh melalui kegiatan pembelajaran di sekolah, sedangkan nonformal dapat dilakukan di luar lingkungan sekolah. Pendidikan formal yang biasanya dilaksanakan di sekolah merupakan salah satu sarana yang tepat untuk meningkatkan kualitas SDM dan untuk mendukung perkembangan IImu Pengetahuan dan Teknologi (IPTEK). Dengan demikian, pendidikan formal harus menyelenggarakan proses pembelajaran yang efektif dan efisien sehingga tujuan pembelajaran dapat tercapai dengan baik.

Mata pelajaran pendidikan jasmani, olahraga, dan kesehatan perlu diberikan kepada peserta didik karena bertujuan untuk mengembangkan keterampilan pengelolaan diri dalam upaya pengembangan dan pemeliharaan kebugaran jasmani serta pola hidup sehat melalui berbagai aktifitas jasmani dan olahraga yang terpilih.

Pembelajaran pendidikan jasmani, olahraga, dan kesehatan merupakan pembelajaran yang bertujuan untuk mendorong pertumbuhan fisik, psikis, keterampilan motorik, pengetahuan, penalaran, serta pembiasaan pola hidup sehat. Dalam standar kompetensi dan kompatensi dasar tingkat SD/MI (bsnp 2007), salah satu ruang lingkup aspek mata pelajaran pendidkan jasmani, olahraga dan kesehatan adalah aktifitas ritmik. Aktifitas ritmik ini disebut senam, yaitu yang meliputi gerak bebas, senam pagi, dan senam aerobik.

Aerobik mempunyai pengertian yang luas dari pada gambaran sehari-hari. Pelopor aerobik adalah Kenneth Cooper pada tahun (1960), dan merupakan konsep latihan baru. menjelaskan bahwa dengan iringan musik dan gerakan yang teratur, dapat membuat tubuh memompa oksigen dan meningkatkan denyut jantung/nadi. Menurut (Rosidah, 2013) senam aerobik atau senam kesegaran jasmani adalah suatu program kesegaran jasmani yang lengkap "meliputi latiahan dan kegembiraan" dimana kita mengekspresikan segala perasaan dengan tertawa, melompat, menendang, jogging, meragang, bergoyang, dan mengombinasikan gerakan-gerakan dansa atau dengan gerakan tari tradisional, tari rakyat bahkan tari kontemporer. Atau pengertian lain suatu aktifitas yang terus menerus yang sekaligus memadukan beberapa gerakan yang akan menguatkan jantung, peredaran darah dan membakar lemak, tubuh menjadi lebih mudah menyalurkan oksigen yang dibutuhkan yang berarti cadangan energi dan vitalis lebih besar. Tetapi banyak sekali tidak dipahami oleh siswa sehingga dalam pelaksanaan senam aerobic disekolah siswa kelihatan belum terampil, karena kurangnya pengontrolan dalam melakukan gerakan senam dan mereka kurang tertarik dengan pembelajaran senam, sehingga siswa merasa bosan dalam pembelajaran ini.

Siswa cenderung melakukan aktifitas lain seperti bermain, menganggu temannya dan tidak serius dalam melakukan gerakan aerobik tersebut. Tetapi ada sebagian siswa yang serius dalam melakukan gerakan aerobik, Padahal rangkaian senam aerobik sangat penting untuk kebugaran jasmani siswa. Senam aerobik bermanfaat untuk mencapai bentuk badan yang diinginkan, memperoleh peningkatan kebugaran dan kesehatan fisik maupun mental, serta dapat mempertahankan berat badan yang ideal, seperti yang dikemukakan oleh bahwa senam aerobik dapat menurunkan presentase lemak badan serta menambah Miafilamen otot, struktur pada tulang dan jaringan ikat, Khusus pengaruhnya terhadap lemak badan. Karena itu, tubuh kita sehat dan bugar, maka kita akan mudah menjalankan aktifitas kita dengan baik.

Keadaan siswa seperti itu jika diabaikan akan menyebabkan siswa mengalami kesulitan dalam mempelajari dan memahami materi atau gerakan senam yang dipelajari. Mengatasi masalah ini diperlukan solusi yang tepat sehingga siswa dapat melakukan senam dengan baik. Salah satu cara yang dapat dilakukan berdasarkan uraian di atas adalah dengan menggunakan metode pembelajaran komando yang dapat mempermudah siswa dalam melakukan gerakan.

Guna mendapatkan gerakan aerobic yang baik maka metode komando layak digunakan karena Metode komando adalah pendekatan mengajar yang paling bergantung pada guru. Tujuannya adalah penampilan yang cermat. Guru menyiapkan semua aspek pengajaran dan ia sepenuhnya bertanggung jawab dan berinisyatif terhadap 
pengajaran dan memantau kemajuan besar dari perkembangan siswanya. Pada dasarnya, gaya ini ditandai dengan penjelasan, demonstrasi dan latihan.

Guru menyiapkan semua aspek pengajaran yang mendukung dan yang efektif. Sasaran metode komando adalah respon langsung terhadap petunjuk yang diberikan, penampilan yang sama/seragam, mengikuti metode yang telah ditentukan, kecepatan dan kecermatan respons, meningkatkan semangat kelompok, dan pengunaan waktu secara efisien (Afif, 2019)

Tujuan metode mengajar komando adalah: untuk mempelajari cara mengejarkan tugas dengan benar dan dalam waktu yang singkat, mengikuti semua keputusan yang dilakukan oleh guru. Dalam metode ini semua aktifitas pembelajaran, keterlaksanaannya hanya dan sangat tergantung pada guru. Dapat dikatakan peserta didik akan bergerak hanya bila gurunya memerintahkannya untuk bergerak. Situasi demikian menyebabkan peserta didik pasif dan tidak diperkenankan berinisyatif. Akibatnya peserta didik tidak mampu mengembangkan kreativitas, khususnya kreativitas dalam bergerak hakikat: respon langsung terhadap stimulus.

\section{METODE}

Jenis penelitian ini adalah tindakan partisipatif (action research). Penelitian ini dilaksanakan pada siswa-siswi di SMA Negeri 7 Ambon yang berjumlah 21 siswa. Dengan teknik pengambilan sampel yaitu random sampling. Indikator keberhasilan pada penelitian ini dievaluasi dengan menggunakan penelitian authentic. Penelitian ini sangat diperlukan dalam meningkatakna efisiensi pengelolahan pendidikan dengan menggunakan siklus untuk melihat peningkatan hasil belajar. Oleh karena penelitian ini merupakan penelitian tindakan maka dilakukan beberapa tahap antara lain: (1) perencanaan tindakan, (2) pelaksanaan tindakan, (3) pengamatan, (4) refleksi. Setelah data diperoleh maka akan diolah secara deskriptif untuk menentukan nilai akhir sebagai bentuk asesmen pembelajaran dengan rumus:

$$
\begin{gathered}
P=\frac{F}{\mathrm{~N}} \times 100 \% \\
(\text { Anas, 2009) }
\end{gathered}
$$

Keterangan :

$P=$ Persentase (\%)

$F=$ Jumlah Jawaban Sampel Untuk Setiap Pertanyaan

$N=$ Banyaknya Sampel

\section{HASIL DAN PEMBAHASAN}

\section{a. Hasil Penelitian}

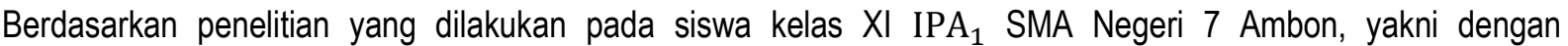
diterapkannya metode komando, peneliti mendapatkan hasil yang sesuai dengan harapan. Atau dengan kata lain, metode komando yang diterapkan ketika melakukan proses pembelajaran, tingkat kemampuan belajar siswa terhadap materi lebih meningkat. Dapat dilihat hasil penelitian sebagai berikut: 
Tabel 1. Hasil Penelitian Siklis 1

\begin{tabular}{|c|c|c|c|c|c|}
\hline \multirow{2}{*}{ Valid } & & Frequency & Percent & \multicolumn{2}{|r|}{$\begin{array}{c}\text { Cumulative } \\
\text { Percent }\end{array}$} \\
\hline & 60.00 & 2 & 9.5 & 9.5 & 9.5 \\
\hline & 62.00 & 1 & 4.8 & 4.8 & 14.3 \\
\hline & 63.00 & 2 & 9.5 & 9.5 & 23.8 \\
\hline & 65.00 & 2 & 9.5 & 9.5 & 33.3 \\
\hline & 70.00 & 1 & 4.8 & 4.8 & 38.1 \\
\hline & 75.00 & 1 & 4.8 & 4.8 & 42.9 \\
\hline & 78.00 & 1 & 4.8 & 4.8 & 47.6 \\
\hline & 79.00 & 1 & 4.8 & 4.8 & 52.4 \\
\hline & 80.00 & 2 & 9.5 & 9.5 & 61.9 \\
\hline & 81.00 & 1 & 4.8 & 4.8 & 66.7 \\
\hline & 82.00 & 2 & 9.5 & 9.5 & 76.2 \\
\hline & 83.00 & 1 & 4.8 & 4.8 & 81.0 \\
\hline & 85.00 & 2 & 9.5 & 9.5 & 90.5 \\
\hline & 87.00 & 2 & 9.5 & 9.5 & 100.0 \\
\hline & Total & 21 & 100.0 & 100.0 & \\
\hline
\end{tabular}

Dari tabel diatas dapat dijelaskan bahwa dengan menerapkan metode komando diperoleh nilai rata-rata kemampuan belajar siswa $74,76 \%$ atau ada 13 siswa yang sudah tuntas belajar. Hasil tersebut menunjukkan bahwa pada siklus pertama secara klasikal siswa belum tuntas belajar, karena siswa yang memperoleh nilai $\geq 75$ hanya sebesar $63,50 \%$ lebih kecil dari presentase ketuntasan yang di kehendaki yaitu $75 \%$. Hal ini disebabkan karena siswa merasa belum malu untuk melakukan gerakan senam aerobik yang diterapkan guru dengan menggunakan metode komando. Dan dilanjutkan pada siklus ke dua dengan hasil sebagai berikut:

Tabel 2. Hasil Penelitian Siklis 2

\begin{tabular}{lrrrrr}
\hline & & & & \multicolumn{2}{c}{ Cumulative } \\
& & Frequency & Percent & Valid Percent & \multicolumn{1}{c}{ Percent } \\
\hline Valid & 77.00 & 1 & 4.8 & 12.5 & 12.5 \\
& 78.00 & 2 & 9.5 & 25.0 & 37.5 \\
& 79.00 & 1 & 4.8 & 12.5 & 50.0 \\
& 80.00 & 4 & 19.0 & 50.0 & 100.0 \\
\cline { 2 - 5 } & Total & 8 & 38.1 & 100.0 & \\
\hline
\end{tabular}

Dan pada siklus ke dua ini menunjukan bahwa delapan siswa yang belum tuntas pada siklus pertama dan diberi penguatan materi dengan koreksi pada tingkat kesalahan mereka maka ke depalan siswa siswi dikatakan tuntas.

\section{B. Pembahasan}

Dari hasil penelitian terlihat bahwa dengan diterapkannya metode komando dalam proses pembelajaran senam aerobik, dan guru memberikan contoh terlebih dahulu sebelum siswa melakukan gerakan senam aerobik maka siswa dengan mudah dan cepat untuk memahami gerakan-gerakan sehingga dapat meningkatkan kemampuan belajarnya. Dalam metode ini, siswa dapat melakukannya sesuai komando yang diberikan lewat gerakan-gerakan dalam lagu yang mereka gunakan untuk melakukan senam aerobik.

Dengan menggunakan metode komando dalam pembelajaran senam aerobik, suasana dilapangan menjadi lebih baik, karena seluruh siswa terfokus pada komando yang diberikan lewat lagu, baik siswa yang melakukan, atau 
siswa lainya maupun guru sebagai pengajar, karena mereka dapat menghayati dan memahami gerakan yang satu dengan yang lain lewat komando tersebut.

\section{SIMPULAN}

Hasil dari penelitian ini dapat disimpulkan bahwa metode komando pada pembelajaran senam aerobik

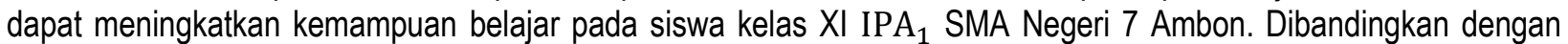
metode lainnya, metode komando sangat baik untuk pembelajaran senam aerobik, karena dengan menggunakan komando siswa tidak hanya mementingkan diri sendiri tapi juga belajar untuk bekerja sama dengan teman lain pada saat melakukan gerakan senam aerobik sehingga terlihat rapi dan serasi.

\section{DAFTAR PUSTAKA}

Afif, M. (2019). Penerapan Metode Sorogan dalam Meningkatkan Baca Kitab di Pondok Pesantren Tarbiyatun Nasyi'in. KABILAH : Journal of Social Community. https://doi.org/10.35127/kbl.v4i2.3592

Anas, S. (2009). Pengantar Statistik Pendidikan. Rajawali Pres.

bsnp 2007. (2017). Wawancara terstruktur dilakukan ketika peneliti sudah menyediakan pertanyaan-pertanyaan kepada sumber informasi yang tersusun secara sistematis. Sedangkan wawancara tidak terstruktur dilakukan secara bebas tanpa menggunakan pedoman wawancara yang tersusun. STILISTIKA: Jurnal Bahasa, Sastra, Dan Pengajarannya.

Rosidah, N. (2013). PERBEDAAN PENGARUH LATIHAN SENAM AEROBIK LOW IMPACT DAN MIX IMPACT TERHADAP TINGKAT KESEGARAN JASMANI PADA SISWA PUTRI SMK NEGERI 1 SURAKARTA TAHUN PELAJARAN 2012/2013. Phederal: Physical Education, Health and Recreation Journal. 